\title{
Filosofie in de rechtszaal ${ }^{*}$
}

\author{
Bert van Roermund
}

\section{Vooraf}

Wat doet een filosoof in de rechtszaal? In die, ietwat botte, formulering rees de vraag naar aanleiding van het optreden van collega Paul Cliteur (Leiden) als getuige voor de verdediging in het Wilders II-proces. Dat optreden bestond uit een rapport ${ }^{1}$ en een verhoor op 3 november $2016 .^{2}$ Cliteur is niet de enige die recent op verzoek van een procespartij rechtsfilosofische bijdragen heeft geleverd aan een rechtsgang. Ook Derk Venema (Nijmegen) is onlangs opgetreden, en wel als gemachtigde in rechtszaken van Pastafariërs. ${ }^{3}$ De Vereniging voor de Wijsbegeerte van het Recht heeft deze casuïstiek geagendeerd voor een discussie tijdens de Wintervergadering 2017. Terugblikkend op het levendige debat ${ }^{4}$ leg ik graag een uitwerking van mijn mondelinge presentatie voor, zodat de gedachtewisseling kan worden voortgezet op een podium waar zij in ieder geval óók thuishoort: de kolommen van dit tijdschrift. De lezers zullen het mij niet kwalijk nemen dat ik de bijdrage van Cliteur aan het Wilders II-proces in deze bijdrage centraal stel. Ik vind haar namelijk uiterst leerzaam op het stuk van fundamentele rechtsvragen, terwijl ik bij de cabareteske Pastafariërs niet verder kom dan de vraag of we niet wat spaarzamer met schaarse procesmiddelen moeten omgaan.

\section{Ter inleiding: mijn vraag en mijn stelling}

Er kan uiteraard geen enkel bezwaar bestaan tegen het feit dat iemand die zich beroepshalve met rechtsfilosofie bezighoudt, in de rechtszaal optreedt als deskundige, daartoe uitgenodigd door partijen of rechter. Als zo iemand zegt dat

* De redactie heeft Paul Cliteur om een reactie gevraagd. Omdat het hoger beroep in de zaakWilders-II nog loopt, acht hij het op dit moment niet opportuun te reageren.

1 Opgenomen in het recente boek van Paul Cliteur, Bardot, Fallaci, Houellebecq en Wilders. Juridische vervolging van religiekritiek en vreemdelingenvrees (Groningen: De Blauwe Tijger, 2016) , hfdst. 2 en 3. Ik dank Paul Cliteur voor de collegiale toezending van een exemplaar. Tevens dank ik de collega's Nick Huls en Maria IJzermans voor commentaar op de eerste versie van deze tekst, alsook de twee anonieme referenten van dit tijdschrift. Zij hebben mij voor menige uitglijer behoed en zijn niet verantwoordelijk voor de resterende.

2 Waarvan het eerste deel te vinden is op https://www.youtube.com/watch?v=hhnyyRNUY9E (geraadpleegd 2 februari 2017).

3 Leden van de Kerk van het Vliegend Spaghettimonster tegen gemeenten die geen rijbewijs willen verstrekken met een foto waarop de aanvrager een vergiet op het hoofd draagt. De Rechtbank Oost-Brabant stelde op 15 februari 2017 de burgemeester van Eindhoven in het gelijk. Vgl. https://uitspraken.rechtspraak.nl/inziendocument?id=ECLI:NL:RBOBR:2017:762 (geraadpleegd 16 februari 2017). (Met dank aan Derk Venema.)

4 Waarbij Cliteur helaas, ondanks een vroegtijdige uitnodiging, niet aanwezig kon zijn wegens verplichtingen in het buitenland. 
hij dat niet enkel zijn burgerplicht acht, maar ook zijn beroepsplicht - zoals Cliteur deed in de rechtszaal zowel als in de media - dan verdient dat respect. Dit houdt onder andere in dat toehoorders of lezers van zulk optreden de politieke voorkeur van de deskundige terzijde laten. Dat doe ik dan ook. Of de deskundige in dit geval wel of niet aanhanger is van, respectievelijk steun verleent aan, de PVV, het Forum voor Democratie, de Partij voor de Dieren, de SP, of welke (Nederlandse) politieke partij dan ook, interesseert mij niet. De vraag die ik wil voorleggen is van een andere orde. Cliteur presenteert zijn vak als 'een filosofische bezinning op de grondslagen van het recht'. Hem is door de verdediging nadrukkelijk om een filosofisch onderzoek gevraagd, meer in het bijzonder om een antwoord op de vraag in hoeverre (on)verdraagzaamheid al dan niet een beperkend criterium zou kunnen zijn ten aanzien van de vrijheid van meningsuiting en, indien dit het geval is, hoe dit begrip moet worden ingevuld. ${ }^{5}$ Welnu, onder welke voorwaarden leent de filosofie van het recht zich voor een dergelijke inzet in een rechtsproces?

Ik zal de stelling verdedigen dat de filosofie van het recht zich daar niet zonder meer toe leent. De wijsheid (sophía) waar zij naar taalt (philein) vereist in verband met de rechtspraak uiterste bezonnenheid (sophrosunè). Je kunt die voorwaarde natuurlijk negeren, om principiële dan wel om opportunistische redenen. Maar dan verander je óf de rechtsgang óf de filosofie ingrijpend. Het eerste kan je de kop kosten, zoals ik zal aantonen aan de hand van de Apologie van Socrates. Maar ook het tweede heeft zijn prijs. Je maakt de filosofie dan tot een verlengstuk van de rechtsgeleerdheid. Dat laatste is natuurlijk niet verboden, en het wordt zelfs algemeen gedaan. Dan echter raakt het recht zijn kritische tegenstem kwijt en dat is niet zonder gevolgen. Ik zal aantonen dat die gevolgen zich in het betoog van Cliteur voordoen. Daarbij besef ik terdege, dat hij zich - in de onderhavige procedure en in ander verband - regelmatig kritisch uitlaat over wetgevende en rechterlijke rechtsvorming, nationale zowel als Europese. Maar deze kritiek heeft naar mijn oordeel het karakter van een alternatieve rechtsleer, die niet de filosofische pertinentie van het recht zelf probeert op te sporen maar vooral op zoek is naar filosofische zinsneden die aansluiten bij een reeds ingenomen juridische positiekeuze.

\section{De eigen aard van filosofie}

Terecht kenmerkt Cliteur zijn vak Encyclopedie als 'een filosofische bezinning op de grondslagen van het recht'. Het woord 'bezinning' is goed gekozen. Niet elke bezinning is filosofisch. Filosofie is een specifiek soort bezinning. Daarover eerst enkele algemeenheden.

1 Elk werkelijk weten - zowel in theoretische als in praktische zin - is een vorm van bezinning. In tegenstelling tot 'geloven', 'gewaarworden' of 'verlangen' is weten reflectief. En wel in de eigenlijke, niet de naïeve, zin van het woord. Het is niet slechts een weerspiegeling van de werkelijkheid in ons denken,

5 http://deeplink.rechtspraak.nl/uitspraak?id=ECLI:NL:RBDHA:2016:3630. 
waarbij wij passief blijven. Het is eerst en vooral het resultaat van een toenadering van degene die kent tot datgene wat gekend wordt. Kennis is gebaseerd op de inzet van een dergelijke openheid of ontvankelijkheid, ${ }^{6}$ juist om te voorkomen dat we de werkelijkheid houden voor onze subjectieve indrukken of grillen. Weten is: kunnen zeggen waar iets uiteindelijk om draait. Waarheid heet dat traditioneel. Of voor wie het analytisch idioom bezigt: 'Ik weet dat $p$ ' impliceert 'Het is het geval dat $p$.'

2 Bezinnen is niet alleen reflectief maar ook reflexief: zich bezinnen op ... Dat betekent dat kennis van meet af aan gevangen zit in de correlatie tussen 'wat' we kennen en 'van waaruit' we kennen. Het gaat daarbij niet om de oppervlakkige vaststelling dat 'alles subjectief is'. Ook in de modellerings- en meettechnieken van de hardste natuurwetenschappen speelt deze correlatie een rol, zoals Van Fraassen ${ }^{7}$ laat zien. Maar bij wetenschap blijft deze zogenaamde indexicaliteit ingebed in een methode, waarbij met name gebruik gemaakt wordt van reducties of vertekeningen die ontleend zijn aan het doel dat wij met het betreffende model voor ogen hebben. Wetenschap is als het ware het tekenen van een plattegrond met een bepaalde functie, waarop wij eerst en vooral moeten zien uit te vinden waar de pijl ' $U$ bent hier' staat.

3 Filosofie als bezinning is (a) hyper-reflectief (we trachten te zeggen waar iets uiteindelijk om gaat) en (b) hyper-reflexief (wij komen altijd zelf mee in het geding). Met andere woorden, waarheid-spreken ${ }^{8}$ is altijd in radicale zin ons waarheid-spreken. Radicaal,

a omdat ons spreken niet bij voorbaat geborgd is door een methode;

b omdat nooit restloos te achterhalen is vanuit welk standpunt we spreken (en we onszelf dus uiteindelijk vreemd blijven ${ }^{9}$ );

c omdat dit spreken voor onze rekening komt en wij erop afgerekend worden;

d en ten slotte omdat waarheid alleen verschijnt als ze ter sprake gebracht wordt.

Om al deze redenen wordt wel betwijfeld of filosofie een wetenschap is. Het antwoord hangt uiteraard af van wat men vooropstelt. Als wetenschap beperkt wordt

6 Vgl. Bernhard Waldenfels, Phänomenologie der Aufmerksamkeit (Frankfurt a.M.: Suhrkamp, 2004).

7 Bas van Fraassen, Scientific Representation: Paradoxes of Perspective (Oxford: Clarendon Press, 2008), 75vv.

8 Het Griekse woord voor 'spreken' in dit verband ( $\lambda \dot{\varepsilon} \gamma \varepsilon v v)$ betekent zowel 'bijeengaren' als 'spreken'. De reflectieve zowel als de reflexieve dimensie van 'spreken' openbaart zich in verschillende lexicale vertakkingen van het enkelvoudige $\lambda \dot{\varepsilon} \gamma \varepsilon v$. De reflexieve modus komt vooral naar voren in mediale samenstellingen als óv $\alpha \lambda \dot{\varepsilon} \gamma o \mu \alpha 1$ en $\dot{\varepsilon} \pi \imath \dot{\varepsilon} \gamma o \mu \alpha 1$, waarbij de voorzetsels een 'richting' of gerichtheid (intentionaliteit) aanduiden. Met name de laatste samenstelling kan ook 'bij zichzelf te rade gaan', 'nadenken' betekenen. Over het conceptuele verband tussen intentionaliteit en reflexiviteit zie bijvoorbeeld H.-N. Castañeda, 'Intentions and the structure of intending,' The Journal of Philosophy 68 (1971): 453-66. Zie verder de betreffende lemmata in Henry George Liddell en Robert Scott, A Greek-English Lexicon. Revised and augmented throughout by Sir Henry Stuart Jones, with the assistance of Roderick McKenzie (Oxford: Clarendon Press. 1940), op http://tinyurl.com/y94fej2g.

9 Vgl. Rudi Visker, Vreemd gaan en vreemd blijven. Filosofie van de multiculturaliteit (Amsterdam: SUN, 2005). 
tot die vormen van 'weten' die bij voorbaat methodisch of modelmatig gezekerd zijn, dan is filosofie geen wetenschap. ${ }^{10}$ Wie daarentegen erkent dat elke wetenschap moet beginnen bij vormen van weten die (nog) niet methodisch of modelmatig gezekerd zijn, zal bereid zijn de filosofie als wetenschap bij uitstek te erkennen.

Wat daar ook van zij, de genoemde kenmerken maken elke vorm van filosofie ten overstaan van het recht uiterst ambigu. Aan de ene kant vertolkt ze precies dat register van waarheid dat in het recht aan de orde is. Dat is in laatste instantie niet de methodisch gezekerde wetenschappelijke waarheid (die van de natuurwetten, de kansberekening en de modellen) maar de waarheid in gewone woorden, de waarheid die wij beloven, ja zweren te spreken omdat we haar zien als ethische opgave. ${ }^{11}$ Aan de andere kant is die vertolking zo oneindig open dat ze strijdt met het gesloten karakter van het recht als een proces dat conflicten moet beëindigen door gezagvolle beslissingen. Anders gezegd, als het aan de filosofie lag, dan had advocaat Knoops het beste een forensische vergadering van de Vereniging voor de Wijsbegeerte van het Recht als deskundige kunnen oproepen. Dat zou ongetwijfeld interessante debatten over Mill, Voltaire, Montesquieu, de scheiding der machten en de vrijheid van meningsuiting hebben opgeleverd. Maar de rechtsgang in het Wilders-proces zou er niet door bevorderd zijn. Niet voor niets blijft de voorstelling van 'De Atheense School' in de Sixtijnse kapel ons fascineren: Plato die naar boven, Aristoteles die naar beneden wijst. Die twee worden het nooit eens. Het enige dat aan hun onenigheid een einde kan maken is een 'symposion', geen gezagvolle beslissing. Filosofische deskundigheid is er alleen in het meervoud. Dat bleek bijvoorbeeld ook in de Verenigde Staten in de Colorado-zaak Evans $v$ Romer, waarin John Finnis en Robert George als getuige-deskundigen optraden voor de beklaagden, en Martha Nussbaum voor de klagers. Hun rapporten werden voorgelegd in 1993. Maar zeven jaar later stelde Randall B. Clark vast dat zij nog steeds bezig waren hun fundamentele verschillen van inzicht van nieuwe brandstof te voorzien, zij het niet meer in de rechtszaal maar in academische publicaties. ${ }^{12}$

10 Vgl. Hans-Georg Gadamer, Wahrheit und Methode. Grundzüge einer philosophischen Hermeneutik (Tübingen: Mohr, 1975 [1960]).

11 Aldus het onderscheid bij Cornelis Verhoeven, Bijna niets (Bilthoven: Amboboeken, 1970), 175vv.

12 Randall B. Clark, 'Platonic Love in a Colorado Courtroom: Martha Nussbaum, John Finnis, and Plato's Laws in Evans v. Romer,' Yale Journal of Law \& the Humanities 12(1) (2000): 1-38, esp. 4: 'As a result of the sharp disagreement between the views expressed (and methods employed) in Nussbaum's and George's testimonies, all three parties saw fit to clarify and expand their arguments: Each of them submitted to the court at least another written explication of his or her own position along with a criticism of the other side. So sharp were their disagreements, however, that, even after Judge Bayless had handed down a verdict in the plaintiff's favor, the antagonists have continued - some to this day - to prosecute their arguments in scholarly fora.' Zie verder daar voor relevante literatuur (met dank aan de referent van NJLP). 


\section{Socrates voor zijn rechters}

We vinden deze ambiguïteit bevestigd wanneer we kijken naar de allereerste introductie van de filosofie in de rechtszaal die ons is overgeleverd: de Apologie van Socrates bij Plato. ${ }^{13}$ Zoals bekend voert Socrates zijn eigen verdediging. We nemen daarvan kennis op een specifiek moment in het proces: het moment waarop er reeds een doodvonnis tegen hem is uitgesproken. Gezaghebbende auteurs weten ons te vertellen (en dit blijkt op het einde van de Apologie ook wel uit de tekst), dat naar toenmalig Grieks strafprocesrecht de volgende fase in de rechtsgang is dat de veroordeelde een andere (uiteraard meestal een lagere) straf bepleit (36b). Daarbij wordt dikwijls op het gemoed van de rechters gewerkt, waarbij men niet schroomt om onder geweeklaag achterblijvende echtgenoten en kinderen ten tonele te voeren. ${ }^{14}$ In het eindoordeel over de straf hebben de rechters dan de bevoegdheid om te middelen tussen het aanvankelijke oordeel en het pleit van de veroordeelde. Het resultaat van dit loven en bieden over een lange reeks casuïstiek is natuurlijk - zo kunnen wij wel vermoeden - dat de rechters in eerste instantie vrij hoog inzetten met hun straf, omdat ze weten dat ze straks nog water in de wijn moeten doen.

De doodstraf voor Socrates was dus waarschijnlijk een hoge inzet, anticiperend op Socrates' tegenvoorstel van een lagere straf. Dat voorstel komt er uiteindelijk ook (30 mima; 38b), maar het staat in geen verhouding tot de geëiste doodstraf, zoals Socrates beseft. Hij wil zichzelf noch de rechters verlagen tot dat niveau van loven en bieden, want rechters moeten de wet toepassen. ${ }^{15}$ Het zou zelfs oneerbiedig zijn tegenover de goden van de stad om rechters tot iets anders te verleiden. In plaats daarvan herneemt hij de eerste fase van het proces en argumenteert over wat al lang niet meer aan de orde is. Het gaat opnieuw over de beschuldiging dat hij de goden van de stad (wij zouden zeggen 'waarden en normen') geen eerbied betuigt, en dat hij de jeugd bederft. Vervolgens gaat het over de opdracht van de filosofie, die nu eenmaal de waarheid betreft en niet de gevestigde opvattingen of de daarop gebouwde machtsposities. Hij duidt zichzelf aan als een paardenhorzel met een vaderlijke prik, een vriend van de polis, die eigenlijk zou moeten aanzitten aan de bestuurdersdis. Hij bepleit een beloning (36a), terwijl een tegenvoor-

13 Voor verwijzingen naar de vindplaatsen in de Apologie gebruik ik ter wille van controleerbaarheid: Plato in Twelve Volumes, Vol. 1. (Cambridge, MA/Londen: Harvard University Press/William Heinemann, 1966), tegenwoordig te raadplegen op http://tinyurl.com/y94o9bsq (geraadpleegd 21 februari 2017). Voor de vertaling koos ik in de meeste gevallen die van Gerard Koolschijn (Symposion Feest, Sokrates' verdediging, Kriton Socrates in de cel, Sterfscène uit Faidon [Amsterdam: Anthenaeum - Polak \& Van Gennep, 2013]) en ik geef aan wanneer ik daarvan afwijk. Koolschijn laat echter de klassieke nummering in de tekst achterwege. Ik ontleen het onderstaande deels ook aan het informatieve, maar wijdlopige Socrates is een mens (A.W.W. Rieter, Socrates is een mens. Tragiek van een levenseinde [Best: Damon, 1998]).

14 Socrates beschrijft het met zoveel woorden in 34d en neemt er afstand van. Vgl. ook 38d: 'medelijden en smeken' (Koolschijn, p. 108); 'weeping and wailing', zoals de Engelse vertaling plastisch luidt.

1535 ; dat is precies wat Cliteur de rechters voorhoudt, maar het is ook het argument waarmee OM en rechtbank zijn verklaring als 'niet ter zake' aanmerken. 
stel voor de straf aan de orde is. Een serieus voorstel komt er niet, dus blijft het eerste oordeel overeind: de doodstraf. Socrates graaft dus zijn eigen graf door filosofie te introduceren in de rechtszaal, en wel op een moment waarop de rechtsgang daar volslagen aan voorbij moest gaan.

Toch vertegenwoordigt Socrates - volgens Plato's tekst, dus filosofisch gezien met deze opstelling precies datgene waar het in het recht om gaat. Want (laat hij zijn leermeester zeggen) zijn daimonion ${ }^{16}$, dat anders altijd protesteert als hij iets doet wat niet in de haak is, protesteerde niet toen hij zijn huis verliet, naar het gerechtsgebouw liep en argumenteerde zoals hij deed. Het daimonion zou hem tegengehouden hebben als zijn optreden niet op zijn plaats geweest zou zijn, maar dat was het naar filosofische maatstaven juist wel. Ook het recht heeft namelijk behoefte aan een 'vragensteller'17, juist omdat het zelf voortdurend poseert als antwoord, ja oplossing, ja zelfs rechtmatig gevolg van een feit. Het recht heeft een tegenstem ${ }^{18}$ nodig tegen de macht waaruit het is ontsprongen. Het is aangewezen op een vertoog dat 'buiten de orde' is, juist omdat het zelf een en al orde is. ${ }^{19}$ De slechtste dienst die de filosofie het recht dan ook kan bewijzen, is haar oude rol van 'dienstmeid' weer op zich te nemen, dit keer niet van de theologie (ancilla theologiae) maar van het recht (ancilla iuris). In die rol zou ze zich bij voorbaat beschikbaar moeten stellen als een vindplaats van argumenten wanneer de juridische argumenten op zijn. Maar de filosofie is er niet om het recht of - for that matter - de mens te redden. In de woorden van Merleau-Ponty: 'De filosofie is geen hospitaal. ${ }^{20}$

Deze distantie is tegelijkertijd een vorm van engagement met het recht, dat wil zeggen met de kern waar het in het recht uiteindelijk om draait. Ook dat valt in de

16 Een 'goddelijk teken' - een raadselachtig begrip in de tekst, vooral omdat het een verzelfstandigd neutrum is van een adjectief en bovendien voortdurend als een tegenhoudende in plaats van een stimulerende kracht wordt afgeschilderd (zie 40avv). Koolschijn (p. 112) kiest voor 'het demonische' en 'het teken van de god', ongetwijfeld tegen de achtergrond van Socrates' eerdere betoog over 'demonen' en 'demonische machten'. Vgl. 31c-d en voor een uitgebreide discussie Rieter, Socrates is een mens, $273 \mathrm{vv}$.

17 29e: 'Als iemand van u dat dan zou tegenspreken en zou beweren er wel aandacht aan te besteden [nl. aan inzicht en waarheid en aan uw ziel, om die zo goed mogelijk te ontwikkelen; BvR] zal $\mathrm{ik}$ hem niet meteen loslaten en ook niet weggaan. Ik zal hem vragen stellen en zijn antwoorden kritisch onderzoeken' (Koolschijn, p. 98).

$18 \mathrm{Al}$ in de eerste regels verklaart Socrates zich 'een vreemdeling' tegenover de spreekwijze van het recht $(17 \mathrm{~d})$.

19 De vroege Habermas (Jürgen Habermas en Niklas Luhmann, Theorie der Gesellschaft oder Sozialtechnologie. Was leistet die Systemforschung? [Theorie Diskussion] [Frankfurt a.M.: Suhrkamp Verlag, 1971], 201) karakteriseerde de Diskurs dan ook als 'Gegeninstitution schlechthin'.

20 Aldus de titel van de intreerede van W. Luijpen aan de TU Delft in 1969, verwijzend naar Maurice Merleau-Ponty, Deuxième entretien privé. La connaisance de l'homme au XXe siècle. Rencontres internationales de Genève VI (1951), red. J. Romains e.a. (Neuchâtel: La Baconnière, 1952), 247. Zie ook de opmerkingen van Merleau-Ponty over Socrates' apologie en de rol van de filosofie in zijn Éloge de la Philosophie (Parijs, Gallimard, 1953). 
Apologie te lezen. ${ }^{21}$ Het is een engagement met de filosofische kern, de waarheid, die uit het recht zelf spreekt en van waaruit het leeft (als het goed is). Die kern is, volgens mij, niet de deugd van rechtvaardigheid, al helpt die deugd zeer bij wat het recht beoogt. Het is eerder de niet-aflatende en bestendige wil om conflicten die de samenleving dreigen te verscheuren te beëindigen door gezagvolle beslissingen. Of het nu een proactieve wetsregel of een reactief rechterlijk oordeel betreft, daar gaat het steeds om. De rest gaat over de vraag hoe je zo'n wil bestendigt en tot uitvoering brengt, hoe je gezag vestigt, enzovoort. Het betrachten van rechtvaardigheid helpt daarbij zeer, maar ook een stevige kennis van wetenschap en technologie en een goede politieke analyse.

Minder ambigu is daarom de verhouding van de filosofie tot de rechtsgeleerdheid. Hier is eerder sprake van een fundamentele keuze dan van ambiguïteit. We kunnen immers scherp onderscheid maken tussen een rechtsfilosofie die uiteindelijk filosofie blijft en een rechtsfilosofie die uiteindelijk bij de rechtsgeleerdheid onderdak vindt en zich beperkt tot een instrumenteel inzetbare Reflexion auf eigenes Tun (Larenz). De rechtsfilosofie moet in dit opzicht een keuze maken: het is van tweeën één. Een dergelijke onontkoombare keuze vinden we bevestigd in de analyse die Leo Strauss maakt van de politieke filosofie, en die langs dezelfde lijnen verloopt. ${ }^{22}$ Zoals de filosofie - naar het woord van Socrates - 'de vriend van de polis' moet zien te worden en niet de knecht, zo moet ze ook 'de vriend van het recht' worden zonder de dienaar van de rechtsgeleerdheid te zijn. Dan zal ze naar mijn mening zich niet rechtstreeks in een rechtsgang moeten mengen ten gunste van een der procespartijen, maar op afstand moeten staan van elke rechtsgang en laten zien wat er eigenlijk aan waarheid op het spel staat. Dat is tenminste wat Socrates deed.

\section{Het betoog van Cliteur}

Cliteur lijkt met zijn optreden een andere keuze te maken: het onderschikken van de filosofie aan de rechtsgeleerdheid. Natuurlijk, op het eerste gezicht doet hij precies het tegenovergestelde. Het lijkt soms alsof hij het recht filosofisch de maat neemt. Maar bij nader inzien, zo wil ik aantonen, gaat die filosofische maat voorbij aan de diepgang van de juridische argumentatie waartegen hij zich keert. Dan rijst de vraag waar de maat voor dient.

21 Vgl. 18a. Hier zou ik dan ook willen afwijken van Fowler's vlakke vertaling in de Harvard-Heine-

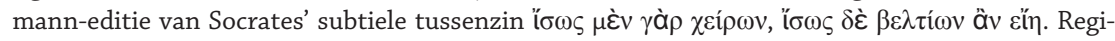
nald E. Allen (Socrates and Legal Obligation [Minneapolis: University of Minnesota Press, 1980]), 38 vertaalt beter: '(...) it may perhaps be poor, but then perhaps an improvement'. Ik vind dat zelfs puntiger dan Koolschijn (p. 82): 'misschien is hij slechter, misschien ook wel beter'. Met andere woorden: op het eerste gezicht is mijn filosofische bijdrage irrelevant in de rechtszaal, maar bijna nader inzien zou zij wel eens de kern kunnen zijn waar het in het recht om gaat.

22 Zie de bijdrage van Catherine en Michael Zuckert in David Janssens, François Coppens en Yuri Yomtov, Leo Strauss. À quoi sert la philosophie politique? (Parijs: PUF, 2014), 15-24. 


\section{a Wat betoogt Cliteur?}

Laat ik eerst het betoog ten processe kort samenvatten. Cliteur acht toepassing van artikel 137c en 137d Sr (groepsbelediging, resp. aanzetten tot haat om redenen van ras, enz.) op de bekende 'minder, minder-uitspraak' van de heer Wilders ten enenmale onjuist. Het door de Hoge Raad geïntroduceerde criterium '(on)verdraagzaamheid' in de uitleg van diezelfde wetsbepalingen moet naar zijn opvatting verdwijnen. ${ }^{23}$ Het is niet een in de wet genoemd criterium van 'belediging' of 'aanzetten tot haat, discriminatie en geweld'. En het is geïntroduceerd na de uitspraken van Wilders, dus wordt het toegepast in strijd met het strafrechtelijk legaliteitsbeginsel. Cliteur waarschuwt dus voor extensieve interpretatie en voor schending van het nullum crimen-beginsel.

Vervolgens gaat hij nader in op het begrip 'tolerantie' zelf. Tolerantie kan helemaal geen beperkend criterium zijn bij het uitoefenen van de vrije meningsuiting, bijvoorbeeld in de zin dat men bij het uitoefenen van de vrije meningsuiting bij voorbaat begrip moet opbrengen voor de gevoeligheid van anderen op het stuk van levensovertuiging op basis van een andere godsdienst of cultuur. Want tolerantie is er juist ter verdediging van de vrijheid van meningsuiting, ook waar die mening door anderen als kwetsend, verontrustend of beledigend wordt ervaren. Ze dient niet om grenzen te stellen aan die vrijheid door te eisen dat men begrip opbrengt voor die gevoelens. Tolerant is men niet tegenover variaties op de eigen opvatting, maar tegenover datgene wat men radicaal afwijst. Dit geldt met name voor politici, in het bijzonder bij blinde vlekken in de beeldvorming. Daarom moet hun vrijheid van expressie groter zijn, niet kleiner. ${ }^{24}$ De grens ligt daar waar politieke pleidooien 'clear and present danger' inhouden omdat zij aanzetten tot

23 HR 16 december 2014, ECLI:NL:HR:2014:3583, NJ 2015/108 m.nt. N. Rozemond (Delano Felter).

24 Met verwijzing naar Max Weber, Politik als Beruf. De politicus moet kunnen 'strijden', expliciete en ferme standpunten innemen ook in heikele onderwerpen (anders dan bijv. ambtenaren of diplomaten). Op de zitting noemt Cliteur het de 'beroepsplicht' van de politicus. Dat moet een kleine vergissing zijn: Beruf in Webers titel betekent 'opdracht'. 
fysiek gewelddadig optreden. ${ }^{25}$ Dus moeten belediging, discriminatie en haat zaaien eigenlijk vervallen als gronden voor beperking van meningsvrijheid (voor politici). Meer dan ooit is verdediging van deze vrijheid van belang. Want de 6500 aangiften tegen Wilders zijn een teken van groeiende erosie van tolerantie, waartegen de rechtsstaat bij monde van de rechter verweer moet bieden. Het Felterarrest ging in dit opzicht de verkeerde kant uit. ${ }^{26}$ Aldus Cliteur.

\section{$b \quad$ Een politiek proces?}

Laat ik vervolgens vooropstellen, dat ik het eens ben met Cliteur (en vele anderen) in zover hij betoogt dat dit proces helemaal niet gevoerd had moeten worden. Het strafrecht loslaten op kwalijke uitspraken in het kader van een verkiezingscampagne verdient geen aanbeveling. In een democratie behoort dit het soort kwaad te zijn dat zichzelf straft. Ik steun eveneens de richting waarin Cliteur een grens zoekt: een Nederlandse versie van het 'clear and present danger'criterium. ${ }^{27}$ Anders dan Cliteur ${ }^{28}$ echter, zou ik 'aanzetten tot haat' en 'aanzetten tot discriminatie' niet schrappen uit de wet, maar 'het gevaar van geweld en onderdrukking' gebruiken als criterium om uit te maken of er sprake is van haat, respectievelijk discriminatie. Het spanningsveld lijkt mij duidelijk. Aan de ene kant hoeft niet iedere kwalijke bejegening van een bevolkingsgroep als haat, discriminatie of belediging te worden opgevat, aan de andere kant moet men de geniepige effecten van zulke bejegeningen ook in de politieke sfeer niet onder-

25 Vgl. Cliteur, Bardot, Fallaci, Houellebecq en Wilders, 56, met verwijzing naar Mill, On Liberty. Maar waar? Uit wat Cliteur citeert maak ik niets op over 'clear and present danger'. Wellicht denkt de auteur aan noot 1 van het hoofdstuk over Freedom of Thought: 'As such, I hold that the instigation to it [i.e., tyrannicide; BvR], in a specific case, may be a proper subject of punishment, but only if an overt act has followed, and at least a probable connexion can be established between the act and the instigation. Even then, it is not a foreign government, but the very government assailed, which alone, in the exercise of self-defence, can legitimately punish attacks directed against its own existence.' Dit is echter geen clear and present danger restriction. Het lijkt er integendeel op dat Mill zijn opvatting over tolerantie alleen maar wenst te verdedigen als voldaan is aan zekere morele normen voor een publieke discussie; en dat beledigende taal en pesterij daarmee onverenigbaar zijn. Dit betoogt hij ook in hfdst. 2, p. 52. 'It is, however, obvious that law and authority have no business with restraining either, while opinion ought, in every instance, to determine its verdict by the circumstances of the individual case; condemning every one, on whichever side of the argument he places himself, in whose mode of advocacy either want of candour, or malignity, bigotry or intolerance of feeling manifest themselves; but not inferring these vices from the side which a person takes, though it be the contrary side of the question to our own: and giving merited honour to every one, whatever opinion he may hold, who has calmness to see and honesty to state what his opponents and their opinions really are, exaggerating nothing to their discredit, keeping nothing back which tells, or can be supposed to tell, in their favour. This is the real morality of public discussion: and if often violated, I am happy to think that there are many controversialists who to a great extent observe it, and a still greater number who conscientiously strive towards it.' Ook hier blijkt nergens van een 'clear and present danger'-grens in het openbaar debat.

26 Zie noot 23.

27 Een indringende analyse van de verschillende versies die dit criterium met name in de Verenigde Staten heeft gekregen geeft bijvoorbeeld Quoc Loc Hong, The Legal Inclusion of Extremist Speech (Nijmegen: Wolf Legal Publishers, 2005). 
schatten. ${ }^{29}$ Kordaat legislatief optreden om artikel 137c en 137d Sr scherper te formuleren lijkt mij dan ook aanbevelenswaardig.

Maar, ten eerste, zo ver is het nog niet; en ten tweede, de kern van de zaak hangt niet af van een meer of minder scherpere formulering. De kern van de zaak is of rechtsorganen door het openen van de zaak in kwestie van politieke vooringenomenheid blijk hebben gegeven; en vervolgens of zij daarmee de verdraagzaamheid in het publieke domein op het spel hebben gezet. Mijn antwoord is twee keer: nee. De eerste vraag is het gemakkelijkst te beantwoorden. Als er op basis van de nu eenmaal geldende wetsbepalingen meer dan 6500 keer aangifte wordt gedaan, zou het OM zeer politiek uit de hoek moeten komen om die naast zich neer te leggen om redenen van inopportuniteit. En vervolgens zou de rechter een zeer politieke beslissing moeten nemen om een $\mathrm{OM}$ dat besluit tot vervolging, nietontvankelijk te verklaren. Het enkele feit dat Wilders zich moet verantwoorden voor de rechter is dus niet het resultaat van politieke vooringenomenheid bij de staande en zittende magistratuur maar van politieke onpartijdigheid. In die zin was Wilders II allesbehalve een politiek proces.

Cliteur ziet dit anders. ${ }^{30}$ Het grote aantal aangiften is voor hem een zorgwekkend teken van 'een geperverteerd soort democratisering', ja van 'justitieel populisme': de rechterlijke macht zou de oren laten hangen naar de stem van de straat, die merkwaardigerwijs tegelijkertijd de stem van de elite is. Een stem die almaar intoleranter wordt in naam van een (ook al 'geperverteerde'31) opvatting van tolerantie. Die opvatting zou erop neerkomen dat het uiten van kritiek op bepaalde, politiek-correcte meningen (uitingen als 'homoseksualiteit is een ziekte', 'de islam is een oorlogszuchtige religie') 'intolerant' zou zijn ten opzichte van homo's, respectievelijk moslims, dus van rechtswege verboden zouden moeten worden. Dat de Hoge Raad daarin meegaat getuigt volgens Cliteur van 'taalverslonzing' en 'denkluiheid' op het hoogste rechterlijke niveau. ${ }^{32}$ Over de inhoud van deze diagnose zo dadelijk meer. Maar eerst dit: er lijkt mij weinig op tegen om vanuit een politiek dan wel politicologisch standpunt te wijzen op de politieke betekenis van opmerkelijke aantallen aangiften door burgers van een rechtsstaat. Je kunt ze (in ieder geval bij hypothese) zien als stemverklaringen buiten het kader van algemene verkiezingen. Maar het gaat te ver om te verdedigen dat ze vanuit een juridisch standpunt, dat wil zeggen vanuit de rolopvatting van de organen van de rechtsstaat (zoals met name de rechterlijke macht), als stemverklaringen mogen worden opgevat. Als het $\mathrm{OM}$ of de rechter dat bij bepaalde aangiften zou doen, dan zouden ze inderdaad een politiek proces optuigen.

29 De bijdrage die de metaforen van 'ongedierte', 'zuivering', 'uitroeiing' hebben geleverd aan de haat tegen de joden, of tegen de Tutsi in radio-uitzendingen in de jaren '33-'40, respectievelijk '91-'94 van de vorige eeuw, is niet te onderschatten. Dezelfde bejegening begon als belediging en eindigde als haat zaaien.

30 Cliteur, Bardot, Fallaci, Houellebecq en Wilders, 61vv.

31 Cliteur, Bardot, Fallaci, Houellebecq en Wilders, 60.

32 Cliteur, Bardot, Fallaci, Houellebecq en Wilders, 59. 


\section{c Onverdraagzaamheid}

Richten we de aandacht vervolgens op Cliteurs zware beschuldigingen aan het adres van de hoogste rechter. Het komt mij voor dat Cliteur een geforceerde uitleg geeft aan wat de Hoge Raad heeft beslist in het Felter-arrest. Het ging daarbij om de strafrechtelijke kwalificatie van afwijzende uitspraken over homoseksualiteit uit de mond van de Amsterdamse politicus Delano Felter. In deze beslissing negen maanden na de gewraakte oproep van Wilders - oordeelde de Hoge Raad met betrekking tot artikelen 137c en 137d Sr dat het bij deze strafbaarstellingen niet uitsluitend gaat om uitlatingen die aanzetten tot haat of geweld of discriminatie, maar ook om uitlatingen die aanzetten tot onverdraagzaamheid. Ik geloof echter niet dat de Hoge Raad - zoals Cliteur betoogt - met deze 'maar ook'-formulering een buitenwettelijk criterium 'verdraagzaamheid' invoert ter beperking van de vrijheid van meningsuiting, alsof alleen die meningen mogen klinken die bij voorbaat rekening houden met, begrip opbrengen voor, tolerant staan tegenover datgene wat sommigen op basis van hun levensovertuiging beledigend, schokkend of zondig vinden. Ik lees alleen maar een nadere en geen verbredende of uitbreidende uitleg van datgene waar het in het wettelijk verbod van discriminatie, haat en daaruit voortvloeiend geweld in de kern om gaat. Ik trek namelijk een parallel met wat er in de tekst van het arrest onmiddellijk aan voorafgaat: de Hoge Raad wil de toepassing van artikel 137c en 137d Sr niet louter gebaseerd zien op 'de wet', maar ook op de kern van de wet: 'de grondbeginselen van de democratische rechtsstaat'. Ook dat is geen uitbreiding van de grondslag van het strafrecht maar een uitleg daarvan.

Cliteur betoogt dat het verbod op 'onverdraagzaamheid' in de zin van het Felterarrest het tegendeel is van verdraagzaamheid in eigenlijke zin. Door onverdraagzaamheid jegens politiek incorrecte meningen strafbaar te achten zou de Hoge Raad ipso facto afbreuk doen aan de deugd van tolerantie in de maatschappelijke verhoudingen. Hierop baseert hij zijn diagnostische paradox dat tegenwoordig in Nederland 'de tolerantie erodeert in naam van de tolerantie'. ${ }^{33}$ Deze paradox verliest echter zijn scherpte wanneer je zou kunnen aantonen dat de Hoge Raad helemaal niet zijn rechtsmacht misbruikt om een extra, buitenwettelijk criterium van strafbaarstelling in te voeren, maar om te formuleren wat ik elders 'het verdwijnpunt van de wet' heb genoemd: ${ }^{34}$ een formule die geen zelfstandige betekenis heeft als criterium, maar waaraan de gestelde criteria hun zin en samenhang ontlenen. ${ }^{35}$ Laat ik toelichten waarom de Hoge Raad in deze niet van denkluiheid kan worden verdacht; integendeel, grotere filosofische scherpte aan de dag heeft gelegd dan Cliteur.

34 Vgl. Bert van Roermund, Het verdwijnpunt van de wet. Een opstel over symboolwerking van wetgeving (Deventer: Tjeenk Willink, 1997).

35 In het civiele recht zijn voorbeelden: 'naar redelijkheid en billijkheid'; 'de zorgvuldigheid die in het maatschappelijk verkeer betaamt'. Op zichzelf genomen zijn dit stoplappen (zie bijv. reeds Hans Nieuwenhuis, Drie beginselen van contractenrecht [Deventer: Kluwer, 1979]) die zonder criteria volstrekt nietszeggend zijn, maar niettemin tot uitdrukking brengen wat precies de pertinentie uitmaakt van deze criteria. 
Cliteur heeft (naar eigen zeggen in de geest van Voltaire ${ }^{36}$ ) een omschrijving gegeven van wat verdraagzaamheid, tolerantie, betekent: een ander de vrijheid gunnen om een mening te verkondigen waar men het fundamenteel niet mee eens is. Die omschrijving lijkt mij te beperkt. De filosofie vormt daarvan het bewijs: zij leeft sinds de pre-Socratici van denkers die het met elkaars meningen fundamenteel oneens zijn. Maar wie tolerantie bepleit in de filosofie (en daarmee in het hele domein van de wetenschap) begrijpt niet waar het over gaat. Verdraagzaamheid heeft alleen normatieve betekenis in het politiek domein; dat wil zeggen: daar waar de strijd om de beste ordening van de samenleving zich afspeelt. In dat domein gaat het niet zomaar om meningen, maar vooral ook om leef- en handelwijzen; en het gaat niet alleen om waar men het fundamenteel mee oneens is, maar ook om wat men verafschuwt. Dat laatste is in de praktijk van groot belang, omdat de afschuw het overgangsgebied markeert waarop we het terrein van de botsing der meningen verlaten en dat van de diepe emoties (haat, wrok) betreden. Het eerste is echter minstens zo belangrijk. Cliteur beschouwt leef- en handelwijzen slechts als expressie van 'meningen'. Voor hem is een godsdienst 'een mening'37; een mening die men 'uitdrukt' door bijvoorbeeld een keppel of een hoofddoek te dragen. Wat hij daarmee - al dan niet bedoeld - miskent is dat voor een gelovige het dragen van zo'n kledingstuk niet het uiten is van een mening maar het beleven van een geloof. En dat geloof is voor gelovigen geen 'mening', hoezeer die opvatting hun ook door de zelfbenoemde vertegenwoordigers van het Verlichtingsdenken wordt opgedrongen. Let wel, persoonlijk heb ik weinig tot niets met een dergelijk geloof, laat staan met de onderliggende godsopvatting. Maar ik wil niet voorbijgaan aan het feit dat ik samenleef met mensen voor wie deze geloofsbeleving geen 'mening' is, maar een waarheid, een plicht, een heilsverwachting, een uitverkiezing. Wie tolerant wil zijn, moet niet enkel aan meningen, maar vooral ook aan deze diepgevoelde leef- en handelwijzen ruimte geven. Wie tolerant wil zijn, moet ook godsdiensten verdragen die niet bereid zijn zich op voorhand tot een mening te laten terugbrengen, zelfs niet ter wille van een liberale 'religion civile' of een 'overlapping consensus'. Ik vrees dat het gebrek aan deze tolerantie (die overigens niet alleen godsdiensten geldt) een belangrijkere oorzaak is van haat en wrok in de westerse samenlevingen dan het opleggen van politieke correctheid.

Zelfs echter bij deze toespitsingen is het niet gemakkelijk om de kern van een onverdraagzame politieke opstelling af te leiden uit wat we verdraagzaamheid noemen. Onverdraagzaam is men niet wanneer met het oneens is met een mening, en zelfs niet wanneer men die mening en de achterliggende leefwijze verafschuwt. Dan zouden we allemaal op een bepaald moment onverdraagzaam zijn. Men zal mij bijvoorbeeld niet onverdraagzaam noemen wanneer ik seksuele omgang met kinderen verafschuw en eventuele pleidooien daarvoor categorisch afwijs. Evenmin ben ik onverdraagzaam wanneer ik pleit voor wetten die dit ver-

36 Voltaire als bron van deze formulering is overigens apocrief. Bij mijn weten is het citaat niet te vinden. Zoals ook het fameuze 'terug naar de natuur' van Rousseau nergens te vinden is.

37 Zij het een 'mening' tussen aanhalingstekens die verder niet toegelicht worden. Zie Cliteur, Bardot, Fallaci, Houellebecq en Wilders, 59-60. 
bieden of overheden die dit verbod handhaven. Dan immers leg ik mijn afschuw voor aan het oordeel van derden. Onverdraagzaam is dat niet, vooropgesteld dat ik mij schik naar de uitkomst van het wetgevingsproces, c.q. naar de uitspraak van een onafhankelijke en onpartijdige rechter. Onverdraagzaam wordt men als men die afschuw, die diepgevoelde antipathie, beschouwt als voldoende grond om die mening of leefwijze onverdraaglijk te achten; dat wil zeggen als iets dat er niet moet zijn, als iets dat hoe dan ook weg moet en dat men dus op goede gronden eigener hand uit de wereld mag helpen. Onverdraagzaam is degene die ertoe neigt, op het terrein van het (voor hem of haar) onverdraaglijke, eigen rechter, ja eigen wetgever te spelen.

Wie een oud boek van Max Scheler herleest ${ }^{38}$ kan vaststellen, dat dit de kern is van de haat. De drang tot vernietiging zit opgesloten in de haat, zoals de drang tot behoeden zit opgesloten in de liefde. ${ }^{39}$ Hier ligt een kwalitatief verschil met afschuw en antipathie. Wat men verafschuwt zal men proberen om te buigen in een gewenste richting; of men zal het de rug toedraaien omdat men er 'niets mee van doen' wenst te hebben. Dikwijls kan men voor die opstelling ook redenen geven. Daarom sprak ik eerder van een 'overgangsgebied' tussen meningen en emoties. Maar evenals liefde is haat de redenen voorbij. Zoals men geen redenen kan aangeven waarom men iemand liefheeft, zo is er ook geen ruimte voor redenen als men iemand haat. Wie haat zegt eigenlijk: het bestaan van deze persoon moet hier en nu eindigen. Dat geldt zelfs in het geval van zelfhaat.

Het is precies deze onverdraagzaamheid die ten grondslag ligt aan wat Cliteur het theoterrorisme noemt: het geloof in een god die gebiedt andersdenkenden te haten. Het verwondert mij dan ook dat hij het de Hoge Raad kwalijk neemt dat deze het begrip 'onverdraagzaamheid' in artikel 137d Sr wil lezen als een eigenmachtig judicieel toevoegsel. De cassatierechter heeft naar mijn inzicht niet toegevoegd maar zeer precies aangewezen wat de kern is van deze wetsbepaling. Ik concludeer dat de Hoge Raad door onverdraagzaamheid te verbieden waarschijnlijk de filosofie van het recht beter gediend heeft dan de rechtsfilosoof Cliteur. En met de zelfgenoegzaamheid de emeritus eigen stel ik dan ook vast dat hiermee eens te meer mijn oude stelling gedemonstreerd wordt: juristen filosoferen meer dan ze denken, maar niet als ze denken dat ze filosoferen.

38 Max Scheler, Wesen und Formen der Sympathie (Bonn: Verlag Friedrich Cohen, 1923), met name deel B, 169vv.

$39 \mathrm{Na}$ afwijzing van drie onjuiste interpretaties van deze stelling (die ik hier vereenvoudigd weergeef), besluit Scheler (Wesen und Formen der Sympathie, 187) in zijn eigen waardenidioom: 'Liebe ist die Bewegung, in der jeder konkret individuelle Gegenstand, der Wert trägt, zu den für ihn und nach seiner idealen Bestimmung möglichen höchsten Wert gelangt; oder in der er sein ideales Wertwesen, das ihm eigentümlich ist, erreicht. Haß aber die entgegengesetzte Bewegung.' 